\title{
NOTES
}

\section{Nutrient Content and Substrate Effect on Fine Root Density and Size Distribution in a Nicaraguan Rain Forest ${ }^{1}$}

\author{
Key words: Nicaragua; nutrient foraging; nutrient heterogeneity; root ingrowth core; tropical wet forest.
}

THAT A HIGH DEGiREL OF NUTRIENI SPATIAL. HETFROGENEITY exists in soil resources, in a broad range of ecosystems, has been confirmed by studies dating back to the 1970s (Hall 1970, Jackson \& Caldwell 1992, Gonzalez \& Zak 1994, Gross \& Pregitzer 1995). Further, this heterogeneity occurs at a scale that would allow an individual plant to experience a variety of belowground nutrient environments. Thus, the ability of a plant to increase nutrient uptake in nutrient-rich patches may be critical to its competitive success.

There are both morphological and physiological methods of foraging for edaphic resources (review in Robinson 1994). In this study, morphological mechanisms of foraging are emphasized, in which changes in the rate and form of root growth allow a plant to take advantage of localized increases in nutrient availability. There are three mechanisms by which morphological foraging can occur: (1) increasing rooting density, (2) increasing the proportion of fine roots, and (3) increasing fine root turnover rates.

Root foraging is often limited to the frequently observed phenomenon of a plant's root system growing prolifically into areas of high nutrient concentration and relatively little into areas that are nutrient-poor. The existence of this type of foraging has been demonstrated in many studies (Hutchings 1988, Pregitzer et al. 1993, Cain 1994, Caldwell 1994, Einsmann et al. 1999); however, it is not universal and some plants show relatively little morphological change in response to increased nutrient availability (Jackson \& Caldwell 1992, Robinson 1994).

While most roots act as a device for nutrient absorption, it is believed that young fine roots are more effective at this than their older, thicker counterparts and therefore responsible for the bulk of nutrient uptake (Nye \& Tinker 1977, Caldwell \& Richards 1983). This leads to the second form of foraging, in which there is an increase in the proportion of fine roots grown into an area in the presence of an increased resource supply.

Because younger, finer roots are most able to absorb nutrients, it may not be energetically worthwhile for a plant to maintain older, less efficient roots. Thus, fine root turnover may increase in a high nutrient environment (Brække 1992, Pregitzer et al. 1995). This third mechanism of morphological root foraging involves not only an increase in fine root growth in nutrient rich areas but also increased root mortality. Root density is not necessarily changed.

This study examined the density and size distribution of roots (mechanisms 1 and 2) in response to three substrates of varying nutrient quality: clay, leaf litter, and dried cow manure. The nutrient content of clay was the lowest and that of manure the highest. The first two substrates, clay and leaf litter, are normally available to plants for rooting. The third treatment, cow manure, was used for its characteristic high availability and slow release of nutrients, traits that make it a popular form of organic fertilizer.

Given the mechanisms of root foraging, the length and diameter of roots growing into a substrate should be directly related to the nutrient quality of the substrate. This suggests two hypotheses about root ingrowth into the substrates tested: (1) root length should be longest in the manure treatment and shortest in the clay treatment; and (2) root diameter should be greatest in the clay treatment and least in the manure treatment. Since $c a 80$ percent of root biomass in this forest is found within the upper $20 \mathrm{~cm}$ of the mineral soil (B. Blair, pers. obs.), these hypotheses were tested using a root ingrowth technique to examine root proliferation into the three substrates within the top $20 \mathrm{~cm}$ of soil.

The experiment was conducted on a $20 \times 50 \mathrm{~m}$ plot within a wet tropical forest on the Caribbean coast of Nicaragua $\left(11^{\circ} 53^{\prime} \mathrm{N}, 83^{\circ} 58^{\prime} \mathrm{W} ; 20 \mathrm{~m}\right.$ elev.), ca $15 \mathrm{~km}$ northwest of the city of Bluefields. Characterized by a patchwork of forest and farmland, this region on Nicaragua's agricultural frontier was struck in 1988 by a category four storm (Hurricane Joan) that severely damaged the forest. The forest's tree species (>60 spp. in a 1 ha plot) are dominated by species characteristic of wet tropical, primary

I Received 25 February 2000; revision accepted 31 January 2001. 
growth rain forests (Vandermeer et al. 2000). The area has a mean monthly temperature of $27^{\circ} \mathrm{C}$ and receives an average annual precipitation of $4800 \mathrm{~mm}$. The forest's soils are Ultisols with a thin organic layer $(<3 \mathrm{~cm})$ and a moderately thick A horizon $(15-20 \mathrm{~cm})$. The wet season lasts for ten months with a short dry season from February through March. This experiment was conducted between March and June 1996.

The study utilized a root-ingrowth core method (Lund et al. 1970, Steen 1991), in which a fixed volume of a rooting substrate is packaged in root penetrable mesh bags. The filled bags or "ingrowth cores" are then incubated in holes established on the forest floor. After a predetermined period, the ingrowth cores are harvested, and the roots within the cores are analyzed.

In this experiment, three substrates were used: (1) clay subsoil obtained below the zone of influence of decomposing plant matter ( $>20 \mathrm{~cm}$ depth; low nutrient availability); (2) leaf litter collected in the surrounding forest (intermediate nutrient availability); and (3) dried cow manure collected from a nearby pasture (high nutrient availability). The substrates were packaged in cylindrical mesh bags $(9 \mathrm{~cm}$ diam. $\times 25 \mathrm{~cm}$ length; $5 \mathrm{~mm}$ mesh diam.) constructed from synthetic minnow seine (North American Sports Products, Detroit, Michigan). Bags were filled to equal volumes to minimize differences in surface area of each treatment. After packaging, the tops of the bags were tied shut with color-coded nylon string. Each treatment was replicated 20 times for a total of 60 ingrowth cores.

A sampling grid was created over the entire $20 \times 50 \mathrm{~m}$ transect, with sampling points at $4 \mathrm{~m}$ intervals. Substrates were allocated haphazardly to each grid point. At each site used for ingrowth core placement, the surface leaf litter was removed and a shallow hole $(10 \times 20 \mathrm{~cm})$ was created using a circular steel coring tube. An ingrowth core was placed in each hole and surrounding soil was firmly pressed down to fill gaps and ensure contact between the mineral soil and the substrate in each bag. Finally, the protruding top of the ingrowth core was marked with fluorescent spray paint for future identification and the previously removed leaf litter was placed over the treatment area.

The experiment was run for three and one-half months before harvest to allow roots to encounter and potentially proliferate into the three substrates. At the end of the designated period, cores were harvested using a small machete to cut roots from around the bags. Once removed, protruding roots were trimmed using scissors.

After harvest, all roots were carefully separated from the substrates and root lengths were measured for each ingrowth core using a line intersect technique (Newman 1966, Tennant 1975). Dead roots, although rare, were included in this analysis when present. Roots were separated into three diameter size classes $(<1,1-3$, and $3-5 \mathrm{~mm}$ ) so that total root length and root length by size class could be calculated. Variability of total root length within treatments was measured by the coefficient of variation $(C V=\bar{x} l$ $\mathrm{SD}$ ). Differences in root length among the substrates were tested by one-way analysis of variance (ANOVA), using log transformed data to meet assumptions of normality.

Five replicates of each substrate type were subsampled and mixed thoroughly. The resulting pooled subsamples were tested for nitrate nitrogen, total nitrogen, and available phosphorus as indicators of their nutrient content. Soil texture analysis was performed on the pooled subsample of the clay substrate. In addition, soil data from an adjacent plot were used to compare soil characteristics of the area with the substrates used in this experiment. Here, a $30 \times 50 \mathrm{~m}$ grid was established and samples of the top 20 $\mathrm{cm}$ of mineral soil were collected at $4 \mathrm{~m}$ intervals, for 104 samples. Average values were used for comparisons.

All analyses were done on air-dried substrate and soil. Nitrate nitrogen was determined using $5 \mathrm{~g}$ subsamples extracted with $2 \mathrm{M} \mathrm{KCL} \mathrm{(Tan} \mathrm{1996)} \mathrm{and} \mathrm{automated} \mathrm{colorimetry} \mathrm{(ALPKEM} \mathrm{RFA} \mathrm{300,}$ ALPKEM Corporation, Wilsonville, Oregon). Total nitrogen was determined by oxidizing $30 \mathrm{mg}$ subsamples of ground soil/substrate in a C-H-N analyzer (NC2500, CE Instruments, Milan, Italy). Soil phosphorus was determined using $2 \mathrm{~g}$ subsamples extracted with $10 \mathrm{ml}$ of Bray's solution (Olsen \& Sommers 1982) and automated colorimetry (ALPKEM RFA 300). Soil texture was determined using the hydrometer method on $25 \mathrm{~g}$ soil subsamples (Tan 1996). The USDA guide for soil textural classification was used for soil classification (Soil Survey Staff 1993).

Soil analysis revealed substantial differences among the substrates' nutrient content (Table 1). As expected, the manure substrate contained the highest quantities of the nutrients measured, the leaf litter contained intermediate amounts, and the clay was the most nutrient-poor. Mineral soil collected from the adjacent plot contained a greater quantity of nutrients than the clay substrate, but less than the leaf 
TABLE 1. Nutrient content of treatment substrates and mineral soil. Clay, leaf litter, and manure data represent pooled samples. Mineral soil data are means $( \pm S E)$.

\begin{tabular}{lccccccc}
\hline Substrate & $\begin{array}{c}\text { Available } \mathrm{P} \\
(\mathrm{mg} / \mathrm{kg})\end{array}$ & $\begin{array}{c}\text { Nitrate } \\
(\mathrm{mg} / \mathrm{kg})\end{array}$ & $\begin{array}{c}\text { Total N } \\
(\%)\end{array}$ & \multicolumn{3}{c}{ Texture (\%) } \\
\hline Clay & $<0.10$ & 0.44 & 0.07 & Sand & Silt & Clay \\
Leaf litter & 6.68 & 147.31 & 1.04 & - & 15 & 67 \\
Manure & 14.23 & 224.31 & 1.29 & - & - & - \\
Mineral soil & $2.17 \pm 0.09$ & $5.19 \pm 0.29$ & $0.42 \pm 0.01$ & $18.00 \pm 0.85$ & $23.00 \pm 0.60$ & $59.00 \pm 0.85$ \\
\hline
\end{tabular}

litter or manure substrates. Both the leaf litter and manure substrates had considerably higher nutrient contents than the clay substrate or mineral soil. This was particularly true of nitrate nitrogen, for which the leaf litter contained 28 times and the manure 43 times the amount of nitrate in the mineral soil. The texture analysis revealed that the clay fraction of the mineral soil averaged 59 percent and the clay fraction of the "clay" substrate averaged 67 percent (Table 1). All mineral soil samples were classified as clay, clay loam, or silty clay loam, with the majority of the samples in the clay category. The "clay" substrate was classified as clay.

The leaf litter and manure ingrowth cores had substantially greater root length in the size classes of less than $1 \mathrm{~mm}$ and $1-3 \mathrm{~mm}$ in diameter than cores containing the clay substrate $(P<0.0001$; Table 2). Similarly, total root length was greater in the leaf litter and manure treatments than in the clay treatment $(P<0.0001$; Table 2$)$; however, in the largest size class $(3-5 \mathrm{~mm} \mathrm{diam}$.), no statistical differences were observed among substrates. In all size classes, there was a trend toward more roots in ingrowth cores containing manure than leaf litter, but these differences were not statistically significant.

Root length distributions among size classes were similar in the leaf litter and manure treatments. In these treatments, ca 80 percent of root lengths were in the smallest size class $(<1 \mathrm{~mm})$ and 20 percent were in the middle size class $(1-3 \mathrm{~mm})$. In contrast, the clay treatment had 67 percent of its roots in the smallest size class and 33 percent in the middle size class. Root diameter was thus skewed toward thicker roots in the low nutrient trearment. Less than 1 percent of root lengths were from roots greater than $3 \mathrm{~mm}$ in diameter in all treatments (Table 2).

All ingrowth cores had roots present at the time of harvest. Variability of root ingrowth among cores of each treatment showed the manure treatment to be highest $(C V=85 \%)$, followed by the clay treatment $(C V=79 \%)$ and finally, the leaf litter treatment $(C V=72 \%)$.

It could be argued that a potential drawback of this study was the difference in textures among the three substrates used. If the low nutrient substrate (i.e., clay) had textural characteristics that inhibited root growth, the results would be confounded. Within this forest, however, the majority of the roots were found in the top $20 \mathrm{~cm}$ layer of mineral soil (B. Blair, pers. obs). While higher in nutrient content, the mineral soil was texturally similar to the clay substrate (Table 1). Although the manure or leaf litter substrate may have promoted increased root growth, this suggests that the textural properties of the clay substrate alone did not inhibit it.

TABLE 2. Mean root length density ( $\pm S E$ ) by diameter size class in each substrate. Root length densities denoted by different letters in a given size class are significantly different $(\mathrm{P}<0.0001)$. Percentages of total root length in each size class by treatment are given in parentheses.

\begin{tabular}{|c|c|c|c|c|c|}
\hline \multirow[b]{2}{*}{ Treatment } & \multirow{2}{*}{$\begin{array}{l}\text { Number of } \\
\text { observations }\end{array}$} & \multicolumn{3}{|c|}{$\begin{array}{l}\text { Root length density }\left(\mathrm{cm} / \mathrm{cm}^{3}\right) \pm S E \\
\text { (Percentage of total root length) }\end{array}$} & \multirow[b]{2}{*}{ Total } \\
\hline & & $<1 \mathrm{~mm}$ & $1-3 \mathrm{~mm}$ & $>3 \mathrm{~mm}$ & \\
\hline Clay & 20 & $\begin{array}{l}0.237^{a} \pm 0.045 \\
(66.4)\end{array}$ & $\begin{array}{l}0.117^{a} \pm 0.018 \\
(32.8)\end{array}$ & $\begin{array}{l}0.002^{a} \pm 0.002 \\
(0.6)\end{array}$ & $0.357^{a} \pm 0.062$ \\
\hline Leaf litter & 20 & $\begin{array}{l}1.970^{\mathrm{b}} \pm 0.348 \\
(81.1)\end{array}$ & $\begin{array}{l}0.453^{b} \pm 0.071 \\
(18.7)\end{array}$ & $\begin{array}{l}0.003^{2} \pm 0.002 \\
(0.1)\end{array}$ & $2.428^{\mathrm{b}} \pm 0.402$ \\
\hline Manure & 20 & $\begin{array}{l}2.571^{b} \pm 0.571 \\
(78.6)\end{array}$ & $\begin{array}{l}0.689^{b} \pm 0.117 \\
(21.1)\end{array}$ & $\begin{array}{l}0.011^{\mathrm{a}} \pm 0.003 \\
(0.3)\end{array}$ & $3.271^{b} \pm 0.648$ \\
\hline
\end{tabular}


While this study suggests that some plant species within this Nicaraguan forest actively forage for nutrients, it is likely that there is a variety of foraging abilities among the species present and that some species do not actively forage. In the forest examined, plants with differing life-forms (woody and herbaceous) and successional status (early and late) were present. Robinson's (1994) review of root foraging studies found that 29 percent of the species examined showed little or no morphological response to patches of increased nutrient availability. Although most species tested in his study were herbaceous plants, other studies examining woody species have found similar results (Huante et al. 1998, Einsmann et al. 1999). Although some non-foraging species may rely on physiological foraging, it appears that nutrient heterogeneity varies temporally, possibly reducing the advantage of effective foraging during certain periods. For example, soil heterogeneity has been shown to vary seasonally (Gupta \& Rorison 1975, Ryle et al. 1996) and during natural succession (Gross et al. 1993).

Within the forest studied here, roots grew more prolifically into substrates of higher nutrient content. Additionally, the proportion of fine roots $(<1 \mathrm{~mm})$ was greater in the richer substrates than in the nutrient-poor substrate. Following other root-ingrowth core experiments done in the wet tropics ( $\mathrm{St}$. John 1983, Cueves \& Medina 1988, Raich et al. 1994, Ostertag 1998), these results are congruous with the previously discussed mechanisms of root foraging. This study supports the hypothesis that plants take advantage of nutrient patches by increasing total root length and fine root production. Further study is needed, however, to determine the ubiquitousness of the observed response among different plant types and its importance to plant competition.

We thank J. Vandermeer and L. D. Potter for their comments on earlier drafts of the manuscript. The Centro de Investigaciones y Documentación de la Costa Atlantica (CIDCA) provided invaluable logistical support and field assistance. This research was supported by grant DEB-9524061 from the National Science Foundation to J. Vandermeer.

BREkKE, F. 1992. Root biomass changes after drainage and fertilization of a low-shrub pine bog. Plant Soil 143: 33-43. CAIN, M. 1994. Consequences of foraging in clonal plant species. Ecology 75: 933-944.

Caldwell, M. 1994. Exploiting nutrients in fertile soil microsites. In M. Caldwell and R. Pearcy (Eds.). Exploitation of environmental heterogeneity in plants, pp. 325-347. Academic Press, San Diego, California.

- - and J. Richards. 1983. Competing root systems: morphology and models of absorption. In T. Givnish (Ed.). On the economy of plant form and function, pp. 251-273. Cambridge University Press, New York, New York.

Cufves, E., and E. Medina. 1988. Nutrient dynamics within Amazonian forests II: fine root growth, nutrient availability and leaf litter decomposition. Oecologia 76: 222-235.

Einsmann, J., R. Jonfs, M. Pu, and R. Mitchell. 1999. Nutrient foraging traits in 10 co-occurring plant species of contrasting life forms. J. Ecol. 87: 609-619.

Gonzalez, O., AND D. ZAK. 1994. Geostatistical analysis of soil properties in a secondary tropical dry forest, St. Lucia, West Indies. Plant Soil 163: 45-54.

Gross, K., A. Peters, and K. Pregitzer. 1993. Fine root growth and demographic responses to nutrient patches in four old field plant species. Oecologia 95: 61-64.

-, AND K. PREGITZER. 1995. Spatial variation in nitrogen availability in three successional plant communities. J. Ecol. 83: 357-367.

Gupta, P., and I. Rouson. 1975. Seasonal differences in the availability of nutrients down a podzolic profile. J. Ecol.63: 521-534.

HALL, J. 1970. Pattern in a chalk grassland community. J. Ecol. 59: 749-762.

Huante, P., E. Rincon, and F. Chamin. 1998. Effect of changing light availability on nutrient foraging in tropical deciduous tree-seedlings. Oikos 82: 449-458.

Hutchings, M. 1988. Differential foraging for resources and structural plasticity in plants. Trends Ecol. Evol. 3: 200204.

Jackson, R., And M. Caldwell. 1992. The scale of nutrient heterogeneity around individual plants and its quantification with geostatistics. Ecology 74: 612-614.

Lund, Z., R. Pearson, and G. Buchanan. 1970. An implanted soil mass technique to study herbicide effects on root growth. Weed Sci. 18: 279-281.

Newman, E. 1966. A method of estimating the total length of root in a sample. J. Appl. Ecol. 3: $139-145$.

Nye, P., And P. Tinker. 1977. Solute movement in the soil-root system. University of California Press, Berkeley, California.

Olsen, S., And L. Sommers. 1982. Phosphorus. In A. Page, R. Miller, and D. Keeney (Eds.). Methods of soil analysis, part 2. Chemical and microbiological properties, 2nd edition, pp. 403-430. American Sociery of Agronomy, Madison, Wisconsin.

OstertaG, R. 1998. Belowground effects of canopy gaps in a tropical wet forest. Ecology 79: 1294-1304.

Pregitzer, K., R. Hendrick, and R. Fogkl. 1993. The demography of fine roots in response to patches of water and nitrogen. New Phytol. 125: 575-580. 
- D. Zak, P. Curtis, M. Kubiske, J. Teer, and C. Vogel.. 1995. Atmospheric $\mathrm{CO}_{2}$, soil nitrogen and turnover of fine roots. New Phytol. 129: 579-585.

Raich, J., R. Riley, AND P. VITousek. 1994. Use of root-ingrowth cores to assess nutrient limitations in forest ecosystems. Can. J. For. Res. 24: 2135-2138.

Robinson, D. 1994. Tansley review no. 73: The responses of plants to non-uniform supplies of nutrients. New Phytol. 127: 635-674.

Ryze, R., M. Caldwell, and J. Manwaring. 1996. Temporal dynamics of soil spatial heterogeneity in sagebrushwheat grass steppe during a growing season. Plant Soil 184: 299-309.

SteEN, E. 1991. Usefulness of the mesh bag method in quantitative root studies. In D. Atkinson (Ed.). Plant root growth: an ecological perspective, pp. 75-86. Blackwell Scientific, Oxford, England.

Soll Surver Staff. 1993. Soil survey manual, United States Department of Agriculture, handbook no. 18. U.S. Government Printing Office, Washington, D.C.

ST. JoHN, T. 1983. Response of tree roots to decomposing organic matter in two lowland Amazonian rain forests. Can. J. For. Res. 13: 346-349.

TAN, K. 1996. Soil sampling, preparation, and analysis. Marcel Dekker, New York, New York.

Tennant, D. 1975. A test of a modified line intersect method of estimating root length. J. Ecol. 63: 995-1001.

Vandermeer, J., I. Granzow de la Cerida, D. Boucher, I. Perfecto, and J. Ruiz. 2000. Hurricane disturbance and tropical tree species diversity. Science 290: 788-791.

\section{Brent C. Blair ${ }^{2}$ and Ivette Perfecto}

School of Natural Resources and Environment

University of Michigan

Dana Building, $430 \mathrm{E}$. University

Ann Arbor, Michigan 48109-1115, U.S.A.

2 Corresponding author. E-mail: chrix@umich.edu

BIOTROPICA 33(4): 701-708 2001

\section{Vegetation Recovery following a High Elevation Fire in the Dominican Republic ${ }^{1}$}

Key words: Baccharis myrsinites; Cordillera Central; Dominican Republic; fire; Juan B. Pérez Rancier National Park; Lyonia spp.; Myrica picardae; Myrsine coriacea; Pinus occidentalis; recovery; regeneration; vegetation.

Fire IS INCREASINGLY RECOGNIZED AS A MAJOR INFLUENCE on vegetation in high mountain ecosystems of the Neotropics. Recent research in Costa Rican and Andean páramo (Williamson et al. 1986; Horn 1989, 1998a; Balslev \& Luteyn 1992; Verweij 1995; Luteyn 1999) and in páramo-like shrublands in Brazil (Safford 2001) indicates that fire may play an integral role in generating or maintaining present-day vegetation patterns in highland ecosystems of the Neotropical mainland. The role of fire in shaping vegetation composition and structure in highland landscapes of the Caribbean, however, has yet to be elucidated.

Here we focus on the ecological impacts of high elevation fires in the Dominican Republic's Cordillera Central, on the island of Hispaniola in the northeast Caribbean. This rugged range includes the Caribbean's highest peak, Pico Duarte $(3087 \mathrm{~m})$, and extensive highlands above $2000 \mathrm{~m}$ dominated by the endemic West Indian pine Pinus occidentalis Swartz. Despite dominance by a single pine species, these plant communities are rich with endemics, and new montane species are still being discovered and described.

Throughout the highlands, pines, shrubs, tussock grasses, and other herbs intermix in complex patterns that may in part reflect recent fires. Signs of recent burning, including charred tree and shrub stems and grass clumps, are ubiquitous in Dominican pine forests; fires are apparently set both by people and

1 Received 31 October 1999; revision accepted 2 May 2001. 